\title{
The Impact of New Technology on China-Japan Economic Development Research
}

\author{
$\operatorname{Jing} \mathrm{Xi}^{1}$ \\ ${ }^{1}$ International Business School, Sichuan International Studies University, Chongqing,400000
}

\begin{abstract}
After the Second World War, Japan played a leading role in economic recovery and became the world's second largest economic power. But in 1985, the Japanese entered the bubble economy. After the bubble burst in the early 1990s, Japan's economy collapsed and fell into a "lost era." Since then, Japan has not fully recovered. The lack of financial supervision bears an inescapable responsibility for the formation, development and bursting of Japan's bubble economy. Japan should probably take comprehensive deepening reforms, especially supply-side structural reforms, as the main tasks of the current and next phases. China and Japan have a long history of economic cooperation and innovation cooperation with a good foundation. At present, some important changes have taken place in the global economic and technological conditions, which have had a trending influence on the economic innovation cooperation between China and Japan. The new technology revolution has greatly expanded the field of Sino-Japanese cooperation and innovated the cooperation method, and the prospect of win-win cooperation between the two sides will be even broader.
\end{abstract}

\section{Introduction}

In the 21 st century, the economic growth rate and development model of China and Japan have aroused widespread concern. China starts the unprecedented fastest economic development growth while Japan's economic development generally shows a continuous downward trend. It is inseparable from the economic, historical, and development environment of China and Japan.

China's economic development was slow during its feudal period. In the late Qing Dynasty with the erosion of Western capitalism, China's self-sufficient natural economy was gradually disintegrated and capitalism was in embryo in China. After the founding of People's Republic of China, China adopted a highly centralized planned economic system which developed into socialist market economic system nowadays(Davis and Cowan, 1966). This is a fundamental reform and innovation of China's economy which is the basic way to realize socialist modernization.

Japan's economic development was slow during World War II. Although people's private consumption declined to a certain extent, the government's receipts was relatively stable. The combination of these two situations took a certain role in promoting the rapid development of the Japanese economy after World War II. In terms of foreign trade, the moderate increase in exports also accelerated the rate of its economic growth. Meanwhile, the degree of freedom and openness of Japan's foreign market had been continuously improved under the backdrop of foreign economic development. After the implementation of the
TPP, some kinds of imported products of Japan were canceled by the United States for certain tariffs which showed how open the Japanese foreign market was(WEEDE, 2004). In addition, Japan's rapid growth in foreign trade also had an indispensable relationship with Japan's financial support and currency environment.

To attract foreign investment, Japan adopted relevant measures which were in line with China's foreign investment policy in supporting industries and had a great benefit for the growth of both Chinese and Japanese companies. At present, the Japanese government hoped to seize the opportunities of China's economic development. This strategy was in accord with China's strategy of accelerating the implementation of free trade, which promised the good development in free trade agreement as well as the regional economy between China and Japan, and will also promote China's economic development at the same time.

\section{The Formation and Development of Chinese Economy}

\subsection{The Chinese Economy in the Feudal Period}

During the Warring States period, the establishment of the feudal system liberated productivity, and the invention of production tools and technological improvements greatly promoted the rapid development of ancient agriculture. The establishment of the feudal system not only promoted the high-speed development of ancient Chinese agriculture, but also directly caused the handicraft industry to gradually transform from slavery to individual 
handicraft. Feudal agriculture and handicraft industry jointly promoted economic development, which also greatly accelerated the development of commodity economy in the ancient China. Then feudal cities gradually developed and Central Plains market became prosperous.

The unification of the Sui Dynasty provided a favorable political and socioeconomic environment for the social and economic development of the Sui Dynasty and the ancient China. The smooth excavation of the BeijingHangzhou Grand Canal strengthened the political and economic development and exchanges between North and South. However, the large-scale peasant wars in the late Sui Dynasty greatly damaged the productivity.

At the beginning of the Tang Dynasty, the empire adjusted its policies in adopting Equally Dividing Field System and implemented the tenure of tenants. Therefore, the economy was prosperous due to the development of agriculture, handicrafts, and commerce. The Tang Dynasty also adopted an enlightened policy to ethnic minorities in the north, and had frequent contacts with ethnic minorities. However, in the middle of the Tang Dynasty, Equally Dividing Field System was severely damaged, and the later splittism of the feudal society caused deadly damage to social productivity again. Afterward, the Chinese economic center began to move to the Central Plains region.

The rulers of the Ming and Qing Dynasties actively adjusted the policies. The economy was substantially restored and developed. Agriculture and handicraft industry had further developed. Industry and commerce had also continued to develop in large cities. On this basis, some cities and regions in the south of the Yangtze River gradually had the germination of industry and capitalism, but the feudal system seriously hindered the development of modern commodity economy and the germination of modern capitalist economy. The self-sufficient natural economy still occupied the dominant position in society.

After the Opium War, a huge number of foreign imports seriously impacted China's self-sufficient natural economy. The traditional structure of China's handicraft industry was forced to be changed, and other handicraft industries were also severely crowded out by foreign industrial products. Although the Westernization Movement promoted the emergence of national capital and private enterprises in China as well as the rapid development of China's modern industry, but the existence of the feudal system was still a major obstacle to the modern capitalism.

\subsection{The Chinese Economy in the period of the Republic of China}

Chinese national capitalism developed in the early period of the Republic of China, and it was even called the "golden age" by the economics community during the First World War. the Revolution of 1911 successfully overthrew the feudal rule of the Qing Dynasty and established the Republic of China. The Nanjing Provisional Government successively promulgated a series of economic policies to revitalize national industry and commerce, which stimulated the enthusiasm of capitalists and laid a solid economic basis for the development of national capitalism. Even if China had become a semi-colonial and semi-feudal society, national capitalism still flourished. The reason is, on the one hand, the outbreak of World War I effectively eased the economic pressure of Western powers' aggression against China, import trade decreased and export trade increased significantly, which provided a rare opportunity to Chinese capitalism. On the other hand, the investment potential of domestic national capital was also expanding continuously. Production technology and equipment as well as business concepts were constantly being improved. In addition, national capitalists strongly supported the campaign of the opposition of the civil war and the boycott of foreign goods. These greatly promoted the further development of contemporary national capitalism in China.

After the Northern Expedition War, the KMT government achieved reunification in China. The KMT regime headed by Chiang Kai-shek began to implement monopoly capitalism policy in the whole nation. It started from the financial field, then gradually penetrated into heavy industry, light industry, etc. After the Anti-Japanese War, the control of the economic lifeline by the KMT regime attained to its peak. The development and formation of national monopoly capitalism affected the survival and development of free economy and capitalism, and changed the direction of China's free capitalist economic development since modern times, resulting in China's inability to set out along the direction of free capitalism.

\subsection{China's economy in the era of new technologies}

At the portals of a new age, socialism with Chinese characteristics successfully completed the first half of modernization process and was standing at a brand new historical starting point. The 19th National Congress of the Communist Party of China made strategic arrangements for the second half of China's modernization process in the next 30 years, and proposed to completely build a well-off society to basically realize socialist modernization, and then accelerated the establishment of a socialist modernization power with Chinese characteristics. This system depicts the journey and blueprint of China's future development. This goal and strategy are also enriched and perfected the strategic theoretical system of socialist modernization with Chinese characteristics, which provides new options for countries around the world who wish to accelerate economic development but maintain their own economic independence. China provides great solutions to human problems.

Driven by the new technological revolution, China's economy has entered a period of rapid development. In the 21 st century, China's rise has entered a fact that is obvious to all. Made in China, China's strength is gradually going to the world's big stage, all of this is China's influence in the world, and all of this comes from China's development of seizing opportunities and its own reform and opening 
up, and China's rapid development The period is also the peak period of the new technological revolution. Figure 1 shows the rate of impact of new technologies on China's economic development in recent years.

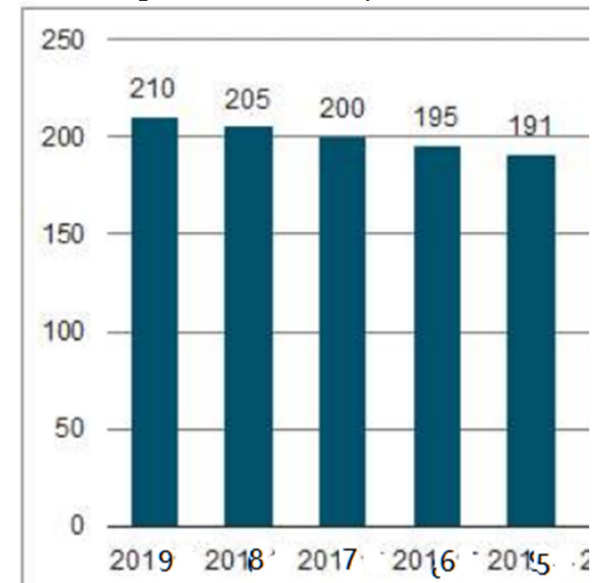

Fig1. the rate of impact of new technologies on China's economic development in recent years

\section{The Formation and Development of Japanese Economy}

\subsection{The Japanese economy before World War I}

From the Meiji Restoration to World War I, Japan's economic development showed "Break through the stereotypes " and " establish a new strategy " characteristics. Japan carried out several reforms in order to develop its economy. The first was to carry out currency reform with the yen as the only currency in the country. The second was to carry out land reform, abolishing the ownership of land by feudal lords, confirming that the private property of the land, and allowing feudal lords to buy and sell the land. Thirdly, the land tax reform stipulated that land tax can be levied on land owners and individuals at $3 \%$ of the land price, and the original land value-added tax shall be replaced by land currency valueadded tax. The last was to implement the policy, "Industry Breeding and Business Initiating Policy ", that importing technology and equipment from abroad by private and government power to establish model factories as examples for private enterprises. The state invested heavily in the field of modern transportation and telecommunications, laying a solid foundation to industrial development and modernization.

\subsection{The Japanese Economy during the Two World Wars}

In order to make up for the small domestic market, the Japanese government began to use force to seize colonies and expand its sphere of influence in order to obtain new, exclusive or semi-exclusive markets. Every time when there was a lack of funds, Japan would attract a lot of foreign capital. For example, "post-war operations" after the Sino-Japanese War and "post-war operations" after the Russo-Japanese War, all of them introduced large amounts of foreign capital through large-scale issuance of bonds and the establishment of joint ventures. After the outbreak of World War I, Japan also increased its sources of capital by expanding foreign trade. At the beginning of the World War I, although Japan made a great progress in capturing the German colonies, but its development was plunged into crisis due to the halt of maritime transportation and the chaos within various foreign countries. It was not until the second half of 1915 that the "war boom" came. Throughout the entire World War I, the competitiveness of Japan's export product was greatly strengthened with a cumulative foreign trade surplus exceeding 1.4 billion yen(Shijie and Jian, 2009).

After the outbreak of the war of aggression against China, Japan looted China's oil resources recklessly. The average speed of development of Japan's domestic petroleum and refining industries was relatively increased. But the production and sales as well as processing of oil consumption in the general economic society slowed down significantly. After the outbreak of the Pacific War, Japan preempted and occupied most of Southeast Asia, and initially completed the strategic ambition of building the " East Asia Economic Rim ". Its domestic industrial economy also obtained a short-term rapid development. The Japan military took this opportunity to transform its industry and economy completely from a semi-industrial war state to a complete war state. During the middle and late World War II, due to the defeat on the battlefield and the indiscriminate bombing and blockade of Japan by the Allied Forces and the United States, the production of Japanese daily necessities basically stopped. Thus, the dying Japan began to enter a pathological economic development with completely madness, and the wealth accumulated since the Meiji Restoration period was consumed totally.

\subsection{Japan's economy in the era of new technologies}

In 1955, the Japanese economy recovered rapidly, even surpassing its pre-war level. It began a process of catching up with Europe and the United States which could be considered as a new historical starting point(Aoki, 2012). After continuous development, "Shenmu Boom", "Iwate Boom", and "Izano Boom" appeared one after another. Japan's sharply economic growth reached a glorious peak and surpassed West Germany in 1968, ranking second in the capitalist world which only next to the United States. In this way, Japan's dominance of economic power among capitalist countries had been further consolidated.

During this period, Japanese economy experienced three major turning points. First, the Japanese economy shifted from high-speed growth to low-speed growth because of the first oil crisis. Nonetheless, after 1978, Japan also completely got rid of the shadow of economic depression with the gradually growth in economic returns of enterprises. Its annual average rate of growth was about $3 \%$ to $5 \%$. Japan was still the country with the fastest economic growth in the world compared with other developed countries(Warner, 2015). Second, Japan shifted from the resource-consumption economic system to the resource-conservation economic system. The impact of 
the two oil crises exposed its shortcomings and vulnerabilities in economy. Japan learned valuable experience from the oil crisis and took active measures and countermeasures in the protection of resources and energy. It achieved remarkable economic growth. Finally, Japan changed from "establishing nation by trading" to "establishing nation by technology." As a "trading nation", Japan's export and processing industry flourished, and the heavy industry economy was also highly developed which enhancing Japan's international competitiveness. At the same time, the Japanese government had put forward an economic strategic plan in the transformation to a technology-intensive and knowledge-intensive industrial economy according to the development trend of the world economic and technological revolution.

Taking the plunge of the stock market as the beginning, Japan's bubble economy declared a collapse and land assets shrank sharply. A large number of heavy industry companies were forced to go bankrupt. In addition, due to the collapse of the IT bubble, the Japanese economy experienced negative growth in 2001. However, the actual economic growth rate in 2002 reached $0.8 \%$. The characteristics of Japan's economic recovery were mainly reflected in the increase in household and sector income, the slow increase in enterprise investment, fiscal revenues and public investment and the rapid increase in foreign trade. Japan gradually emerged from the shadow of the bubble economy with the enterprise quality improved and the bad debts normalized. But there were still some economic problems to be solved, such as the deflation, the disequilibrium in economic recovery, the depression in the stock market and land prices, the slow growth in export, the increasing price in crude oil, the uncertainties in the world economy and other issues.

\section{Comparison in Economic Development between China and Japan}

\subsection{Comparison of economic development conditions and situations}

The economic gap between China and Japan formed and expanded in modern times. Before the Meiji Restoration, both China and Japan were feudal and monarchical countries. A series of capitalist economic reforms and measures implemented by the Meiji Restoration which made the Japanese economy embark on a path of modern economic development, which also widened the economic gap between China and Japan. During the Meiji Restoration period, China experienced the "Western Movement". However, the country's development of politics and economy was far behind by Japan because the "Westernization Movement" was extremely restricted by the feudal rule of the Qing Dynasty and the weakness of the Chinese national bourgeoisie.

Japan embarked on a path of aggression as its crisis intensified. China and other Asian countries were successively invaded and plundered by Japan. The continuous wars led to the decline of China's national strength and the inability in economic development. Although Japan ended in failure in World War II, its domestic development was normal except for Hiroshima and Nagasaki. History proved that the starting points of economic construction and development in China and Japan were very different, which led to the economic gap between the two countries.

After World War II, Japan quickly rebuilt its economy, and its rapid development thereafter created a "world miracle". However, after entering the early 1990s, the Japanese economy fell into long-term negative growth with the burst of the bubble economy, while the Chinese economy experienced rapid growth at that time(Overholt, 2002). Nowadays, China can take advantage of monetary policy and stimulus measures in economic growth to enable the Chinese economy to recover from the financial crisis. The huge economic achievements and development have made China become the second largest economic power in the world at that time.

\subsection{Comparison of Economic Development Direction}

In the 21 st century, China's economic development has entered a track of sustained and rapid growth with its GDP ranks top 2 in the world. But it still has a long way from being an economic power whether considering from the per capita income of urban residents or the population structure and its quality. China still has a long way to go to survive and develop. In the next 10 years, China's survival and development will be closely linked to the Chinese nation. At the same time, the concept of "China Threat" will not only disappear, but also may become more and more intensified. In this regard, China must have sufficient ideological preparations, setting its own direction and position. No matter what China's development and changes will be in the next 10 years, China will not deviate from the main line of "peaceful development."

In recent years, due to Japan 's economic recovery and constant quantitative easing monetary policy, the exchange rate of the yen against the RMB has been relatively stable, and the job market has been in good condition. In the future, the trend of short-term rapid growth of Japanese economy is worth being expected, although the impetus for long-term recovery is still insufficient. The Japanese economy will continue to maintain a certain trend of the recovery and growth. However, because of the limitation by the size of the domestic consumer goods market and the structure of the domestic population, the Japanese economy will continue to keep low and steady growth in the next five years. At the same time, it will continue to face the uncertain risks from Trump's policies in the next five years.

\section{Conclusion}

After the war, the Japanese government adopted policy"Key Industries" to invest limited capital in the production of coal and steel, and then used the investment in these two pillar industries as an economic lever to promote the development of the entire Japanese steel industry. At the same time, the United States had to vigorously support the 
development of the Japanese economy to meet its global strategic needs under such international situation. During the Korean Peninsula War, Japan's mining industries were significantly active and the economy bottomed out. After the Korean War, the Japanese government vigorously developed export trade by imitation and introduction, selling low-cost and low-priced products to countries around the world. However, the economic crisis behind the prosperity caused Japan to retreat in the 1990s. In the new century, although Japanese economy is in the recovery period, it still deadly dulls due to problems such as weak recovery, sluggish consumption and severe aging.

After the Warring States period, China's domestic economy and market were unified, industrial and agricultural modern machinery as well as various financing tools appeared successively in the 1990s. The continued investment in infrastructure expanded China's capital accumulation and become a leading industry in quite a long-term period. China's development is a classic Rostow model. China's economic development is facing a major structural transformation now, that is, from laborintensive industries to capital-intensive and technologyintensive industries. In other words, China's socialist economic development is no longer a matter of speed, but a structural issue. We must pay attention to not only the contrast the economic fluctuation between the two countries, but also the problems which arise in the development process. We have to strive to solve these problems to promote the rapid and healthy development of its economy. We should see the fluctuation of economic development from every turning point, summing up experience and drawing lessons from history.

\section{References}

1. Yang Huiping. A study on China's economy development[J]. Statistics and Decision, 2010(24):83-84,.

2. Chen Qianwen. Comparative Economic Development in China and Japan. [J]. Japanese Journal of Political Science, 2014, 033(002):14-18,27.

3. Yang Zhiyong. Research on the combined model of real-time traffic volume Book Review: Japan's Economy[J]. 2015(3):104-108

4. Zhang Ning, Li Xiang, Lu Keke. Analysis and research of the combination of gray system and neural network algorithm [J]. Shipbuilding Technology, 2015, v.35; No.241(11):44-46.

5. Long Zhao. The Five-Phases of Economic Development and Institutional Evolution in China and Japan [J]. Electronic Journal, 2015, 000(023): 125-126. 